\title{
Correlation of Serum Magnesium with Lipid Profile in CKD Patients on Maintenance Hemodialysis
}

\author{
Darshana Verma ${ }^{1}$, Saurabh Chahande ${ }^{2}$ \\ Department of Medicine, Hamidia Hospital and Gandhi Medical College, Bhopal, India
}

\begin{abstract}
This study was performed to determine the correlation between serum magnesium (Mg) and lipid profile in patients on maintenance hemodialysis (MHD). This hospital-based cross-sectional observational study was conducted at the Department of Medicine, Hamidia Hospital and Gandhi Medical College, Bhopal during period of May 2014 to Nov 2014. Fifty patients with end-stage kidney disease on MHD treatment (29 males and 21 females) were studied. The mean frequency being two to three sessions/week of hemodialysis and each session lasted for four hours. After obtaining informed written consent, the general information of each patient was recorded on a proforma. After overnight fasting, blood samples was drawn for complete hemogram, blood urea, serum creatinine, lipid profile and serum Mg. Dyslipidemia was defined as presence of total cholesterol (TC), triglyceride (TG) or low-density lipoprotein (LDL) levels more than 95th percentile for age and gender or high-density lipoprotein (HDL) levels less than 35 mg/dL. Descriptive and inferential statistical analyses were performed using SPSS version 20.0.The mean age of the study patients was $45.46 \pm 15.60$ years Serum magnesium in CKD patients significantly correlated with Age $(P<0.001)$, systolic blood pressure $(p<0.001)$, serum Triglyceride levels $(P=0.029)$, FBS $(p=0.04)$ and Mean CIMT $(p<0.01)$. There was no significant correlation between serumMg and serum cholestrol and serum HDL. The serum TG and cholesterol levels were significantly increased while HDL-c was significantly lower in MHD patients. We conclude that serum magnesium correlated positively with HDL and correlated negatively with total cholesterol both insignificantly but had significant negative correlation with serum triglyceride levels. The abnormalities of lipid metabolism, such as hyper-triglyceridemia, elevated LP-a and low HDL-c, could contribute to atherosclerosis and cardiovascular disease in hemodialysis patients.
\end{abstract}

Keywords: Serum Magnesium, CKD, Hemodialysis, Cimt, Atherosclerosis

\section{Introduction}

Dyslipidemia is highly prevalent in patients on maintenance hemodialysis (MHD), with predominance of the atherogenic triad, i.e. hypertriglyceridemia, elevated very low density lipoprotein (VLDL) and reduced high-density lipoprotein (HDL).[1]The risk factors for coronary heart disease (CHD) in the general population remain predictive of CHD among patients with chronic kidney disease (CKD) as well.[2] Cardiovascular disease is the leading cause of death in patients on MHD, accounting for almost $50 \%$ of the deaths.[3]The incidence of cardiac death in dialysis and transplant patients has been estimated to be four- to 20 -folds higher than in the general population.[4]Hyperlipidemia has been incriminated as a risk factor for atherosclerotic vascular disease in dialyzed patients, [5] and is characterized by hypertriglyceridemia without cholesterol accumulation. Other dyslipidemias consist of decreased HDL cholesterol and elevated serum lipoprotein (LP-a); the lowdensitylipoprotein (LDL) cholesterol is usually not elevated. LP-a is an independent risk factor for cardiovascular disease.[6] A number of investigators have shown an increase in LPain HD patients. Cressman et al have suggested that elevated levels of lipoprotein also correlate with cardiovascular mortality. Elevated serum magnesium $(\mathrm{Mg})$ can be a problem in patients on MHD. Because kidneys are the major route of excretion of $\mathrm{Mg}$ from the body, increased serum Mg would be expected in patients with renal insufficiency.[7]Mg may be normal or decreased in dialysis patients, which is probably due to decreased dietary intake combined with impaired intestinal absorption. In patients on chronic $\mathrm{HD}$, the major determinant of $\mathrm{Mg}$ balance is concentration of $\mathrm{Mg}$ in the dialysate. Thus, in patients with $\mathrm{CKD}$, there may be reduced intake, impaired absorption from the intestine, use of diuretics and acidosis, which may result in decreased serum $\mathrm{Mg}$, whereas reduced renal excretion may cause accumulation of $\mathrm{Mg}$ resulting in increased serum $\mathrm{Mg}$ levels in CRF patients. Bone concentration and total body $\mathrm{Mg}$ also appear to be increased.[8]Data have shown a correlation between dyslipidemia and serum $\mathrm{Mg}$ concentration in patients on HD. Therefore, we designed this study to assess the association between serumMg and dyslipidemia in patients on end-stage renal disease.

\section{Patients and Methods}

Fifty patients with diagnosis of chronic kidney disease who are on routine dialysis for more than 3 months admitted to medicine department of Hamidia Hospital and GMC Bhopal were taken for the study. The patient excluded were patient having Acute renal failure, History of carotid surgery, Malignancy, Significant illness and patients on Magnesium therapy. Information was collected through prepared proforma for each patient and informed consent was obtained from each participant. The study protocol was approved by Institutional Ethics Committee of Gandhi medical college, Bhopal. History of smoking, DM, hypertension. Cardiovascular event, hyperlipidemia and use of statin and magnesium therapy were evaluated. A complete clinical examination was done with special reference to signs of CKD like pallor, puffiness of face etc. Blood pressure was measured with standard mercury sphygmomanometer and cuff, after the subject had rested in supine position for 15 minutes.. Hypertension was defined as blood pressure $>140 / 90 \mathrm{~mm} \mathrm{Hg}$ or if patient is already on antihypertensive drug. The morning urine sample and blood samples were collected after 8 hours of overnight fasting for complete hemogram, blood urea levels, serum creatinine levels, serum elecrolytes and lipid profile (Total cholesterol,

\section{Volume 5 Issue 2, February 2016}




\section{International Journal of Science and Research (IJSR) \\ ISSN (Online): 2319-7064}

Index Copernicus Value (2013): 6.14 | Impact Factor (2014): 5.611

Triglycerides and HDL) and serum magnesium. All the biochemical parameters were measured by standard laboratory technique. Glomerular filtration rate (GFR) was calculated by Cockcroft Gault Equation. Dialysis was performed using DIALOG + DIALYSIS MACHINE with ultrafiltration rate from 500 to $800 \mathrm{ml} / \mathrm{hr}$ and temperature of diasylate to be maintained at $36.50 \mathrm{C}$. the diasylate solution used was as follows: Sodium $7900 \mathrm{mmol} / \mathrm{L}$, Pottasium 2.00 $\mathrm{mmol} / \mathrm{L}$, Calcium $1.75 \mathrm{mmol} / \mathrm{L}$, Magnesium $0.75 \mathrm{mmol} / \mathrm{L}$, Acetate $4.0 \mathrm{mmol} / \mathrm{L}$ and Chloride $86.0 \mathrm{mmol} / \mathrm{L}$.

\section{Statistical Methods:}

For different parameters, mean and standard deviation were calculated.. The values of $\mathrm{P}$ which are $<0.05$ were treated as significant. The qualitative variables (like sex, diabetes) were compared using $\chi 2$ test. The statistical software SPSS Ver.20 was used for statistical analysis. Univariate correlation analysis was used to confirm the significance of variables with serum magnesium levels.

\section{Results}

The study included 50 cases of CKD Patients on dialysis; 29 male and 21 females. The mean age of the studied CKD patients was $45.46 \pm 15.60$ years (Range 18-76). Maximum patient in the study were in age group of 50 to 60 years. The mean haemoglobin was $8.86 \pm 1.71 \mathrm{gm} / \mathrm{dl}$, mean blood urea was $149.9 \pm 60.81$ and mean creatinine was $6.88 \pm 3.24$ $\mathrm{mg} / \mathrm{dl}$. Diabetes Mellitus was the etiology of CKD in $28 \%$ patients. The serum magnesium was significantly correlated with diabetes in the study. $(\mathrm{P}<0.001)$. The mean BMI in CKD patients was $18.37 \pm 1.82 \mathrm{~kg} / \mathrm{m} 2$.In the present study most of the CKD patients was in Stage 5. i.e. 43 cases. Total serum Cholesterol levels ( $>200 \mathrm{mg} / \mathrm{dl}$ ) was found higher than normal in 15 cases and the mean was $174.1 \pm 44.62$. The mean Serum Triglyceride levels were $144.54 \pm 58.09$ $\mathrm{mg} / \mathrm{dl}$ in CKD patients and it correlated significantly with serum magnesium. The mean HDL-C levels were $39.26 \pm$ $6.40 \mathrm{mg} / \mathrm{dl}$ were lower in CKD patients found. in 30 patients among 50 cases. Serum magnesium in CKD patients significantly correlated with Age $(\mathrm{P}<0.001)$, systolic blood pressure $(\mathrm{p}<0.001)$, serum Triglyceride levels $(\mathrm{P}=0.029)$, FBS $(p=0.04)$ and Mean CIMT $(p<0.01)$.

\section{BASIC CLINICAL AND LABORATORY CHARACTERISTIC OF STUDY} PATIENTS (N=50)

\begin{tabular}{|c|c|}
\hline Parameters & $\mathrm{MEAN} \pm \mathrm{SD}$ \\
\hline Age & $45.46 \pm 15.60$ \\
\hline $\operatorname{Sex}(M / F)$ & $29 / 21$ \\
\hline Height & $158.94 \pm 8.37$ \\
\hline Weight & $46.46 \pm 5.07$ \\
\hline BMI & $18.37 \pm 1.82$ \\
\hline Diabetes (Y/N) & $14 / 36$ \\
\hline Pulse & $74.5 \pm 14.80$ \\
\hline Systolic blood pressure & $162.24 \pm 20.40$ \\
\hline Diastolic blood pressure & $98.08 \pm 12.45$ \\
\hline Haemoglobin & $8.86 \pm 1.71$ \\
\hline Fasting blood sugar & $126.8 \pm 74.24$ \\
\hline Blood urea & $149.9 \pm 60.81$ \\
\hline Serum creatinine & $6.88=3.24$ \\
\hline GFR & $10.95 \pm 7.14$ \\
\hline CKD stage $(3 / 4 / 5)$ & $3 / 4 / 43$ \\
\hline Number of dialysis & $20.98 \pm 14.48$ \\
\hline Serum albumin & $3.01=0.56$ \\
\hline HDL & $39.26 \pm 6.40$ \\
\hline Triglycerides & $144.54 \pm 58.09$ \\
\hline Total cholesterol & $174.1 \pm 44.62$ \\
\hline Magnesium & $2.35=0.98$ \\
\hline Mean CIMT & $0.78=0.23$ \\
\hline
\end{tabular}

CORRELATION WITH RESPECT TO SERUM MACNESIUM:

\begin{tabular}{|c|c|c|}
\hline Parameters & $\mathbf{P}$ & $\mathbf{R}$ \\
\hline Age & $0.001[3]$ & -0.523 \\
\hline Beight & 0.551 & -0.086 \\
\hline Weipht & 0.363 & -0.131 \\
\hline BMII & 0.692 & 20.057 \\
\hline Pulise & 0.288 & 20.153 \\
\hline Systolic blood pressure & $0.00 ![3]$ & -0.459 \\
\hline Diastolic blood pressure & 0.166 & 2.199 \\
\hline Hsemoplobin & 0.157 & -0.203 \\
\hline Fastiag blood sugar & $0.040[1]$ & -0.397 \\
\hline Blood urea & 0.366 & 0.131 \\
\hline Serum creatiaise & 0.749 & -0.046 \\
\hline GFR & 0.904 & 0.018 \\
\hline Number of dalysis & 0.394 & -0.122 \\
\hline SERUM ALBUMDN & 0908 & 0.017 \\
\hline HDL & 0.245 & 0.167 \\
\hline Triglycenides & $0.029[1]$ & $-0,310$ \\
\hline Total cholesterol & 0.079 & -0.250 \\
\hline Mesa CDMT & $0.001[1]$ & -0.536 \\
\hline
\end{tabular}


International Journal of Science and Research (IJSR)

ISSN (Online): 2319-7064

Index Copernicus Value (2013): 6.14 | Impact Factor (2014): 5.611

MINIMUM AND MAXIMUM VALUES OF LIPID PROFILE

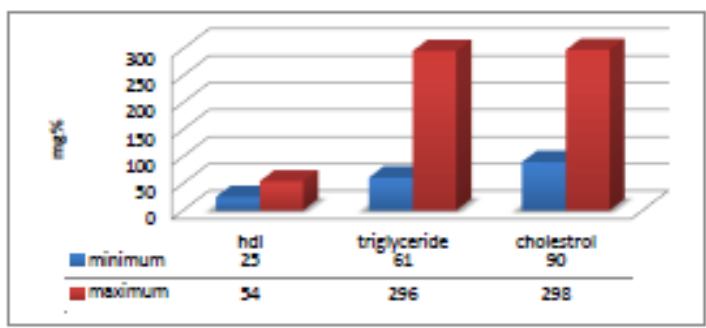

DISTRIBUTION OF PATIENTS AS PER SERUM MAGNESIUM AND HDL.

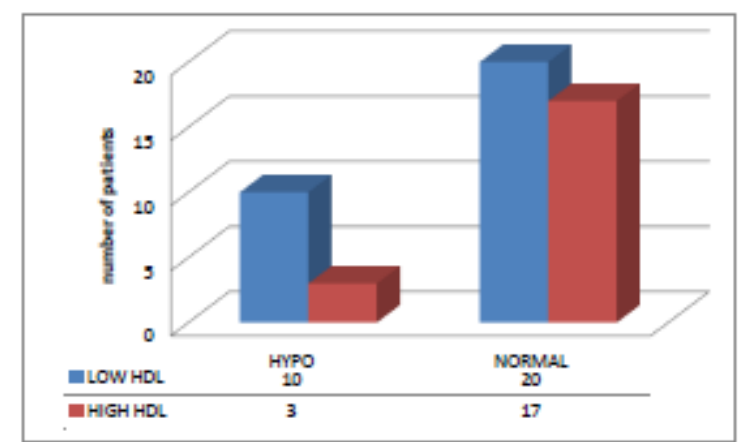

It was found that out of 13 hypomagnesemic patients, 10 had low HDL level and 3 had high HDL level WHICH IS STASTICALL Y NONSIGNIFICANT. $(\mathrm{P}=0.14)$

DISTRIBUTION OF PATIENTS AS PER SERUM MAGNESIUM AND TRIGLYCERIDES

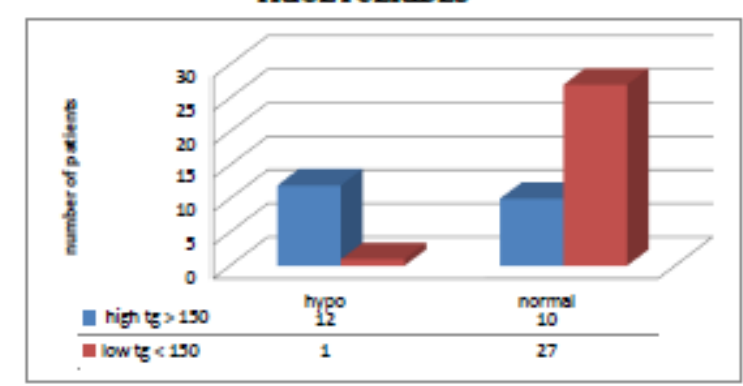

Out of 13 patients with low magnesium level, 12 cases had increased triglyceride level which is statistically significant. $(\mathrm{p}<0.001)$

\section{Discussion}

In our study, the lipid profile was derranged in relation to serum magnesium. Magnesium showed positive correlation with HDL. ie $(p=0.14)$ but was not significant. The magnesium was significantly negatively correlated with serum triglycerides, with $\mathrm{p}$ value $(\mathrm{p}<0.001)$. Magnesium was negatively correlated with total cholesterol levels $p$ value $(\mathrm{p}=0.096)$ which is not significant. Thus the lower serum magnesium level may be associated with dyslipidemia in patients on maintance hemodialysis the pattern of dyslipidemia in our study showed hypertriglyceridemia, increases cholesterol and decreased HDL. These lipid abnormalities are well recognised risk factors for atherosclerotic vascular disease in HD patients and thus there is strong need to focus on underlying causes and treatment of hyperlipidemia.

In J. Elementol, [9] No statistically significant effect of magnesium concentration on the content of lipids analysed in blood serum was found.. Magnesium content in blood serum was also positively correlated with HDL cholesterol in men of both groups. A positive effect on LDL-cholesterol was observed in the group of older women and that of younger men. However, also small negative correlation between $\mathrm{Mg}$ and LDL-cholesterol contents was obtained in older men. Similarly we found positive correlation of serum magnesium with HDL and negative correlation of magnesium with cholesterol and triglycerides. In Nasri, Baradaran et al 2004, [10].Meaningful positive correlation (but statistically non-significant) was obtained between $\mathrm{Mg}$ and total cholesterol. In Feng Liu et al, [11]98 chronic HD patients were recruited), high-density lipoprotein cholesterol

\section{DISTRIBUTION OF PATIENTS AS PER SERUM MAGNESIUM AND TRIGLYCERIDES}

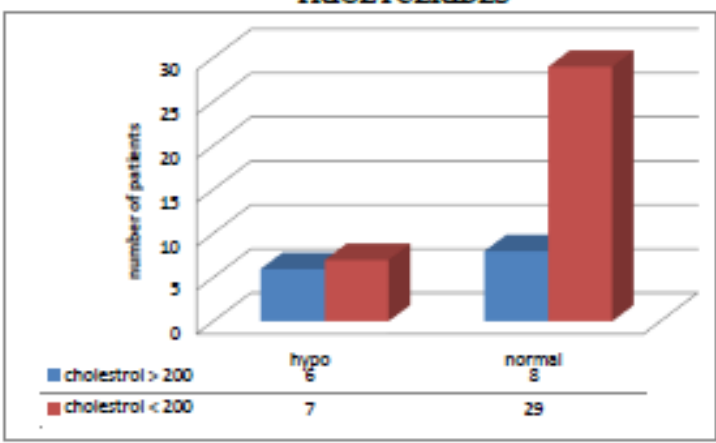

It was found that out of 13 hypoma gresaemic patients, 6 had increased cholesterol level and 7 had normal cholesterol which is statistically insignificant. $(\mathrm{P}=0.096)$

(HDL-c) levels, carotid artery plaque (CAP), and carotid intima-media thickness (CIMT) (all $\mathrm{p}<0.05$, respectively) were higher in patients with low serum magnesium There was no significant correlation between $\mathrm{Mg}$ and low-density lipoprotein cholesterol (LDL-c), lipoprotein-a (LP-a), cholesterol (TC), serum triglycerides (TG) ( $>0.05$, respectively)in contrast we found significant correlation with triglycerides and non significant with cholesterol and HDL. In Ansari MR et al, [12] studied 50 patients and concludes that there was a significant positive correlation between serum $\mathrm{Mg}$ and serum lipoprotein-a (LP-a) $(\mathrm{r}=0.40, \mathrm{P}<$ $0.007)$, serum HDL $(\mathrm{r}=0.31, \mathrm{P}<0.01)$ and serum TG $(\mathrm{r}=$ $0.35, \mathrm{P}<0.005)$. There was no significant correlation between serum $\mathrm{Mg}$ and serum LDL-c and serum TC. The serum TG and LP-a levels were significantly increased while HDL-c was significantly lower in MHD patients. The serum TC, LDL-c and very low-density lipoprotein-c were not significantly elevated. In Robles NR et al [13], twenty-five hemodialysis patients reported a positive significant correlation between serum magnesium levels and serum total cholesterol, and serum triglycerides.

\section{Conclusion}

Magnesium may affect the metabolism of TG and HDL in liver and kidneys, and it may be involved in enzymes responsible for lipoprotein synthesis, but these factors are not clearly understood and further large studies are needed in this regard. Our results indicate that patients with CKD undergoing MHD show significant dyslipidemia. As a first means of controlling hyperlipidemia, body weight normalization, dietary modification, regular exercise and education about diet should be applied. The association of 
dyslipidemia with serum $\mathrm{Mg}$ levels is not clearly understood, and further large clinical studies are needed to understand this association better.

\section{References}

[1] Pennell P, Leclercq B, Delahunty MI, Walters BA. The utility of non-HDL in managing dyslipidemia of stage 5 chronic kidney diseases. ClinNephrol 2006;66(5):33647.

[2] Soubassi LP, Papadakis ED, Theodoropoulos IK, et al. Incidence and risk factors of coronary artery disease in patients on chronic hemodialysis. IntArtif Organs 2007;30(3):253-7.

[3] Al Wakeel JS, Mitwalli AH, Al Mohaya S, et al. Morbidity and mortality in ESRD patients on dialysis. Saudi J Kidney Dis Transpl 2002;13 (4):473-7.

[4] Manske CL, Kasiske BL. Lipid abnormalities after renal transplantation. In: Keane WF, Stein JH, JH, eds. Lipids and renal disease. Contemporary Issues in Nephrology, Churchill Livingstone, New York, 1991;37-61.

[5] Keane WF, Oda H. Lipid abnormalities in end stage renal disease Nephrol Dial Transplant 1998;13(suppl $1): 45-9$.

[6] Kronenberg F, Kathrein H, Ko“nig P, et al. Apolipoprotein(a) phenotypes predict the risk for carotid atherosclerosis in patients with end-stage renal disease. ArteriosclerThromb 1994; 14: 1405-11.

[7] Mountokalakis TD. Magnesium metabolism in chronic renal failure. Magnes Res 1990;3(2): 121-7.

[8] Lindeman RD. Chronic renal failure and magnesium metabolism. Magnesium 1986;5(5-6): 293-300.

[9] J. Elementol., et al Evaluation of the correlations between magnesium concentration and selected serum lipid components in women and men of different age with chronic kidney failure2010, 15(2): 321-329

[10] Nasri H, Baradaran A. Correlation of serum magnesium with dyslipidemia in maintenance hemodialysis patients. Actamedica2004; 47:263- 265.

[11]Feng Liu, XintianZhanng et al. Corelataion of serum magnesium with cardiovascular risk factors in maintenance hemodialysis patients. A cross sectional study. Magnes res 2013 july - sep ; 26(3); 100-8

[12] Ansari MR,, Maheshwari N et al : Correlation of serum magnesium with dyslipidemia in patients on maintenance hemodialysis Saudi j kidney dis transplant. 2012 Jan;23(1):21-5.

[13] Robles NR, Escola JM, Albarran L, Espada R, Cruz A. Correlation of serum magnesium and serum lipid levels in hemodialysis patients. Dialysis \& Transplantation 1998, volum $27,10: 644.648$ oct.. 